YEARBOOK
of ANTITRUST
and REGULATORY
STUDIES
www.yars.wz.uw.edu.pl
Peer-reviewed scientific periodical, focusing on legal and economic issues of antitrust and regulation. Creative Commons Attribution-No Derivative Works 3.0 Poland License.

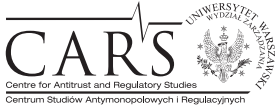

Centre for Antitrust and Regulatory Studies, University of Warsaw, Faculty of Management www.cars.wZ.uw.edu.pl

\title{
Package on Actions for Damages Based on Breaches of EU Competition Rules: Can One Size Fit All?
}

\author{
by \\ Sofia Oliveira Pais* and Anna Piszcz**
}

\section{CONTENTS}

I. Antitrust private enforcement in the European Union context

II. Collective redress

1. Model of collective redress - the Portuguese experience

2. Contingency fees - the Polish experience

III. The Damages Directive - selected problems

1. Prohibition of overcompensation

2. Joint and several liability

3. Effect of national antitrust decisions

IV. Conclusions

\section{Abstract}

On 17 April 2014, the Proposal for a Directive on antitrust damages actions was accepted by the European Parliament and sent to the EU Council of Ministers for final approval. In addition, a Recommendation was adopted in 2013 on common principles for injunctive and compensatory collective redress mechanisms in the Member States to meet the need for a coherent European approach to antitrust private enforcement. This package comes at a time when private antitrust enforcement is rapidly evolving in a number of Member States. At the same time however, it establishes several legal solutions that do not fit well with existing

* Professor of Law at the Faculty of Law, Catholic University of Portugal, Jean Monnet Chair, Coordinator of the Católica Research Centre for the Future of Law - Porto. Sections I and II.1 were written by Sofia Oliveira Pais whilst Section IV is a common part.

** Assistant Professor at the Department of Public Economic Law, Faculty of Law, University of Białystok (Poland); member of the Advisory Board to the UOKiK President; piszcz@uwb. edu.pl. Section II.2 and III were written by Anna Piszcz whilst Section IV is a common part. 
national instruments. The aim of this article is to address, in particular, Portuguese and Polish experiences on a number of specific issues surrounding antitrust private enforcement, such as collective redress and contingency fees. Some doubts will also be raised concerning the solutions established in the European package, suggesting that national experiences should not be overlooked.

\section{Résumé}

Le 17 avril 2014, la proposition de la directive relative aux actions antitrust en dommages et intérêts a été acceptée par le Parlement européen et envoyé au Conseil de l'UE pour l'adoption finale. En outre, une recommandation a été adoptée en 2013 sur des principes communs applicables aux méchanismes de recours collectif en cassation et en réparation dans les États membres pour répondre à la nécessité d'une approche européenne cohérente à l'application privée antitrust. Ce paquet est livré à un moment où l'application privée antitrust évolue rapidement dans un certain nombre d'États membres. Mais en même temps, il établit plusieurs solutions juridiques qui ne correspondent pas bien avec les instruments nationaux existants. Le but de cet article est d'examiner, en particulier, les expériences portugais et polonais sur un certain nombre de questions spécifiques entourant l'application privée antitrust, tels que le recours collectif en cessation et des honoraires. Des doutes seront également soulevés concernant les solutions établies dans le cadre du paquet européen, en suggèrant que les expériences nationales ne doivent pas être négligées.

Classifications and key words: private enforcement; antitrust damages; EU competition rules; Commission package; collective redress; contingency fees

\section{Antitrust private enforcement in the EU context}

In the United States of America, private enforcement of antitrust is usually considered a mature system ${ }^{1}$ which constitutes more than $90 \%$ of all antitrust cases. However, even though it apparently lacks an empirical

${ }^{1}$ In the ironic words of Albert Foer and Jonathan Cuneo, the "US in undoubtedly the leader in private enforcement, but much of the world seems to interpret the US experience as a 'toxic litigation cocktail' to be avoided rather than emulated", The International Handbook on Private Enforcement of Competition Law, ed. by A. Foer and J.W. Cuneo, Edward Elgar Publishing 2012, p. xii. In the European context, on the other hand, the view that public enforcement would be much better than private enforcement was, apparently, well developed at least in the beginning of the EU; see, for instance, W.P.J. Wils, "Should Private Antitrust Enforcement Be Encouraged in Europe?” (2003) 26(3) World Competition 473. 
basis $^{2}$, there is a common criticism of private actions, particularly class action, in that settlements are "judicial blackmail" 3 based not on the merit of the action but rather on the fear of an unpredictable judgement. In the light of the above, EU policy-makers should proceed cautiously in adopting American antitrust principles and the instrument of class action. In fact, while its litigation culture and the characteristics of US civil procedure have indeed favoured a well-developed system of private enforcement, they have, nevertheless, also allowed some excesses which are difficult to revert.

By contrast, competition law has been mainly enforced by public authorities (DG Competition) ${ }^{4}$ in the European Union. Nevertheless, the Commission has, apparently, encouraged private antitrust enforcement for several years now, in order to strengthen the effectiveness of competition rules and optimize the use of its scarce resources ${ }^{5}$. Furthermore, the European Court of Justice (ECJ) ruled in the Courage Crehan case $^{6}$ that full effectiveness of antitrust rules would "be put at risk if it were not open to any individual to claim damages for loss caused to him" by conducts liable to restrict competition. Victim compensation and deterrence would, therefore, be the aims of private damages actions, which need to be strengthened in order to overcome the state of "astonishing diversity and total underdevelopment"7 of private enforcement in Europe (even if recent research may challenge those conclusions ${ }^{8}$ ).

According to the Commission, up to an estimated 20 billion EUR per year are not recovered through the EU in damages from competition infringements ${ }^{9}$.

2 According to R.H. Lande this "view provides no systematic empirical basis for its factual predicates", cf. "Benefits of private enforcement: empirical background" [in:] The International Handbook..., op. cit., p. 4, note 6.

3 Castano v. American Tobacco Co., 84 F.3d 734, 746 (5th Cir. 1996).

4 A.P. Komninos, "Public and Private Antitrust Enforcement in Europe: Complement? Overlap?" (2006) 3(1) Competition Law Review 6.

5 European Commission Green Paper, "Damages actions for breach of the EC antitrust rules", 19.12.2005, COM (2006) 672 final and the previous Ashurst Report "Study on the conditions of claims for damages in case of infringements of EC Competition rules", available http://ec.europa.eu/competition/antitrust/actionsdamages/comparative_report_clean_en.pdf (20.05.2014).

${ }^{6}$ ECJ judgment of 20 September 2001, C-453/99, ECR I-6297, paras 26-27.

7 Ashurst study, op. cit., p. 1.

8 According to C. Hodges, in contrast with the Ashurst study, the findings of the research reported in the book edited by B. Rodgers (Competition Law Comparative Private Enforcement and Collective Redress across the EU, Wolters Kluwer, International Competition Law Series, 2012), show "that there is considerably more private enforcement of competition law than had been previously imagined"), cf. "Fast, Effective and Low Redress: How do public and private enforcement and ADR compare?" [in:] Competition Law Comparative..., op. cit., p. 255.

9 N. Kroes, European Commissioner for Competition Policy, White Paper on Antitrust Damages Actions, Brussels 4.11.2008, p. 3, available at http:/ec.europa.eu/competition/ speeches/text/juri_speech_en.pdf (20.05.2014). 
Similarly, out of the 54 final cartel and antitrust prohibition decisions taken by the Commission in the period 2006-2012 "only 15 were followed by one or more follow-on actions for damages in one or more Member States". The majority of the latter was brought in a limited number of countries only, mainly the UK, Germany and the Netherlands ${ }^{10}$.

In this context, it was not surprising that the European Commission issued on 11 June 2013 a Proposal for a Directive of the European Parliament and of the Council on certain rules governing actions for damages under national law for infringements of the competition law provisions of the Member States and of the European Union ${ }^{11}$ (hereafter: Damages Directive). The draft Directive's first aim is, on one hand, to "optimize" the interaction between private and public enforcement, notably as regards the protection of leniency programmes. On the other hand, it is to ensure effective damages actions before national courts of EU Member States. On 17 April 2014, the Proposal of the Damages Directive was accepted by the European Parliament and sent to the EU Council of Ministers for final approval. To meet the need for a coherent European approach to private enforcement of competition law ${ }^{12}$, the Commission adopted in addition a non-binding Communication and a Practical Guide on quantifying of harm in antitrust infringements ${ }^{13}$, and a Recommendation on common principles for injunctive and compensatory collective redress mechanisms in the Member States concerning violations of rights granted under Union Law (hereafter: Recommendation) ${ }^{14}$. This package comes at a time when private antitrust enforcement is rapidly evolving in some Member States. It establishes, however, several solutions that do not fit well with existing national instruments including Portuguese experiences on the model of collective redress and Polish practice regarding contingency fees.

10 Commission Staff Working Document: Impact assessment report - Damages actions for breach of the EU antitrust rules Accompanying the proposal for a Directive of the European Parliament and the Council, Strasbourg, 11.06.2013 SWD (2013) 203 final no. 52.

$11 \operatorname{COM}(2013) 404$ final, (Damages Directive). Not yet Published in the Official Journal as of 11.10.2014.

12 Although the Recommendation applies to "consumer protection, competition, environment protection, protection of personal data, financial services legislation and investor protection [and] in any other areas where collective claims for injunctions or damages in respect of violations of the rights granted under Union law would be relevant" (para 7), this paper will focus on competition issues.

13 C (2013) 3440, 11.06.2013.

14 2013/396/EU, OJ L 201/60, 26.07.2013. 


\section{Collective redress}

\section{Model of collective redress - the Portuguese experience}

One of the key issues of the debate concerning the enhancement of private enforcement of competition law concerns "class actions". Class actions played a central role in the American system on collective redress for antitrust infringements, but raise several doubts in the EU context.

According to the Commission, collective redress is "a procedural mechanism that allows, for reasons of procedural economy and/or efficiency of enforcement, many similar legal claims to be bundled into a single court action" 15 . It has several advantages, such as facilitating access to justice in cases where low damages are not worth pursuing through individual claims. However, those measures must not attract abusive litigation and should not provide any economic incentives to bring speculative claims (as is the case in the US $)^{16}$.

To attain those goals, the Recommendation puts forward a set of principles relating to judicial as well as out-of-court collective redress, that should be common across the EU, taking into account the legal traditions of EU Member States and the need to prevent abuses. One of the main concerns of the Recommendation relates to the legal standing necessary to bring a collective action. The Commission speaks for an opt-in approach to representative actions which contrasts the opt-out system effective in the US and some Member States, including Portugal.

Clearly, a representative action is "brought by a representative entity (can also be a public authority) on behalf of a defined group of individuals or legal persons who claim to have been harmed by the same alleged infringement"17. It can follow the opt-out model where the judgement is binding on all individuals that belong to the defined group except for those who explicitly opted out. Alternatively, it can follow the opt-in model where the judgement is binding on those who opted in, while all other individuals remain free to pursue their damages claims individually ${ }^{18}$. The Commission favours the opt-in model even if experience shows that it is not very effective as claimants are usually lazy,

15 Communication from the Commission to the European Parliament, The Council, The European Economic and Social Committee and the Committee of the Regions, "Towards a European Horizontal Framework for Collective Redress" (hereafter: Communication), COM

(2013) 401 final, para. 1.2.

16 Communication, para 3.

17 Communication, para 3.3.

18 Communication, para 3.4. 
especially when damages are low, and will thus fail to opt-in ${ }^{19}$. The opt-in model is favoured by the Commission because it is compatible with the legal traditions of the Member States, respects the freedom of potential claimants to decide whether to take part in the litigation or not, and avoids abuses, such as overcompensating class representatives ${ }^{20}$. In fact, opt-out group actions seem to be most useful where individual claims are difficult to prove or when the value of such claims is too low to motivate consumers to participate, reducing, in addition, transaction and information $\operatorname{costs}^{21}$. Furthermore, recent surveys on relevant American jurisprudence show that the standpoint taken by the Commission fails to consider the evolution of the jurisprudence of US Federal Courts which tries to establish "strict safeguards" to minimize "the risks of 'unfairness' and 'defendant's blackmail'"22.

Nevertheless, the Recommendation favours the opt-in model and the Commission has already explained that "any exception to this principle, by law or by court order, should be duly justified by reasons of sound administration of justice" 23 .

Portugal is one of the EU Member States that has an opt-out collective redress model called 'Ação Popular' (Popular Action, hereafter: PA). The PA has not been used frequently, even if it has been considered "the most extensive form of collective action based on the 'opt-out model' available in the EU"24.

The PA is mentioned in Article 52(3) of the Portuguese Constitution: "Everyone shall be granted the right of popular actions, to include the right to apply for the adequate compensation for an aggrieved party or parties, in

19 Towards..., op. cit., pp. 11-12. In fact, studies show that the participation rate in the opt-in model is usually less than $1 \%$ and in the opt-out model more than $97 \%$. See BEUC, The European Consumers' Association, "European Group Action Ten Golden Rules", at R. Gaudet, "Turning a blind eye: the Commission's rejection of opt-out class actions overlooks Swedish, Norwegian, Danish and Dutch experience" (2009) 30(3) European Competition Law Review 108.

20 These arguments have already been presented by the Commission in the White Paper, but - as Gaudet already criticized - the Commission "did not explain how this might occur", R. Gaudet, “Turning...”, op. cit., p. 107-108.

21 J. Douglas Richards, "Aggregation of claims" [in:] The International Handbook..., op. cit., p. 129.

22 A. Andreangeli, "A view from across the Atlantic: Recent developments in the CaseLaw of the US Federal Courts on Class Certification in Antitrust Cases" [in:] Competition Law Comparative Private Enforcement and Collective Redress across the EU, Wolters Kluwer, International Competition Law Series 2012, (ed.) B. Rodgers, p. 249.

23 Communication, para 1.3.

${ }^{24}$ C. Leskinen, "Collective Actions: Rethinking Funding and National Cost Rules" (2011) 8(1) The Competition Law Review 91, who mentions, besides Portugal, the existence of opt-out collective actions in the Netherlands and Denmark. See also Gaudet, "Turning...", op. cit., p. 111. 
such cases and under such terms as the law may determine either personally or via associations that purport to defend the interests in question. That right shall be exercised namely to (...) promote the prevention, cessation or judicial prosecution of offences against public health, consumer rights, the quality of life or the preservation for environment and the cultural heritage".

This constitutional right was implemented by Law 83/95 of 31 August 1995 (Popular Action Act, hereafter: PAA). It should be noted that the PAA has a broad scope and that the list of protected interests contained therein is not exhaustive $^{25}$. However, although the PAA is applicable to the protection of diffuse collective and homogenous individual interests, it does not explicitly refer to the protection of competition. Nevertheless, the compensation of damages arising from antitrust infringements can be sought through the PA mechanism as the list of interests in Article 1 PAA is not exhaustive and the Portuguese Supreme Court did not refuse that solution ${ }^{26}$.

Special procedural rules apply also, different from common declaratory actions, concerning collection of evidence, suspensory effect, and court costs. Article 17 PAA provides that "[i]n the popular action and within the key issues defined by the parties, it is up to the judge's own initiative to collect evidence, and [the judge] is not bound by the initiative of the parties". Article 18 PAA adds that "[e]ven if a particular appeal has no suspensive effect, in general terms, the judge may, in a class action, give it that effect, to prevent damage irreparable or difficult to repair". Finally, Article 20 PAA concerns court costs and expenses. Accordingly, the claimant is exempt from the payment of costs if the application is partially granted; if the claim is totally unsuccessful, the claimant will be obliged to pay an amount fixed by the judge between $10 \%$ and $50 \%$ of the costs that would be normally payable, taking into account the claimant's economic situation and the formal or substantive reason for the

25 On this topic see H. Sousa Antunes, "Class Actions, Group Litigation and Other Forms of Collective Litigation (Portuguese Report)" (2009) 622 The Annals of the American Academy of Political and Social Science 161, S. Oliveira Pais, "A união faz a força? Breves reflexões sobre os mecanismos colectivos de reparação no contexto da aplicação privada do direito da concorrência da União" (artigo) [in:] Liber Amicorum em Homenagem ao Professor Doutor Mota Campos, Coimbra editora 2013, p. 873; S. Oliveira Pais, "Entre clemência e responsabilidade - Uma história de sucesso? - Ac. do Tribunal de Justiça (Grande Secção), de 14 de Junho de 2011, Proc. C-360/09” (2012) 37 Cadernos de Direito Privado 1; L. Rossi, M. Sousa Ferro, "Private enforcement of competition law in Portugal (II): Actio Populari - Facts, fictions and dreams" (2013) IV(13) Revista de Concorrência e Regulação 35.

${ }^{26}$ In fact, we agree with L. Rossi and M. Sousa Ferro when they suggest that the Supreme Court in its decision of 7.10.2003 confirmed that the Popular Action may apply to promote competition, cf., "Private enforcement...”, op. cit., pp. 49-50. In addition, it should be mentioned that as there are no specific provisions concerning the enforcement of competition law, general provisions, such as Articles 483 and 562 (rules on tort liability) of the Portuguese Civil Code, will apply. 
dismissal. Furthermore, it is the court that establishes attorney fees to reflect the complexity and the amount of the claim (Article 21 PAA).

In terms of substantive issues, legal standing and how compensation should be decided in the PA are probably the most controversial concepts in the Portuguese context.

Standing to initiate a PA is granted to: 1) any citizen, 2) a legally constituted association or foundation (as long as it has legal personality, its powers expressly include interests covered by the PA, and if it is not engaged in any type of professional business competing with companies or liberal professionals), and 3) the public prosecutor's office, which may replace the claimants if the contested behaviour endangers the interests involved (Articles 2 and 3 PAA). In addition, the application is subject to preliminary assessment and may be dismissed by the judge if its success is considered unlikely (Article 13 PAA). But, if the action does proceed, the claimants will represent all holders of rights or interests who suffered damages as a result of the given antitrust infringements and did not opt-out.

It is worth stressing that companies, even small and medium ones, do not have direct legal standing and can only seek compensation through individuals, associations or foundations.

It is also worth noting that the PAA does not establish a minimum number of claimants, as opposed to the American class action experience. In fact, in the US, Rule 23 of Federal Rules of Civil Procedure establishes certain requirements for a case to proceed as an opt-out class action. These include: 1) numerosity ("the class is so numerous that joinder of all members is impracticable"27);2) commonality ("there are questions of law or fact common to the class"28); 3) typicality ("the claims or defenses of the representative parties are typical of the claims or defenses of the class"29); 4) adequacy of representation ("the representative parties will fairly and adequately protect the interests of the class ${ }^{30}$ ); 5) predominance ("questions of law or fact common to the members of the class predominant over any questions affecting only individual members" 31 ); and 6) superiority ("a class action is superior to other available methods for fairly and efficiently adjudicating the controversy" 32 ). Analysing these requirements in the light of US experiences, J. Douglas Richard concluded that predominance is the most controversial

\footnotetext{
27 Rule 23 (a) (1).

28 Rule 23 (a) (2).

29 Rule 23 (a) (3).

30 Rule 23 (a) (4).

31 Rule 23 (b) (3).

32 Rule 23 (b) (3).
} 
requirement in antitrust class actions. The easiest to satisfy is numerosity, conventionally mentioned as benchmark forty "overcharged purchasers" 33

The PAA did not set up all these requirements - it did not establish a minimum number of claimants. Still, there is apparently a general consensus that legal standing "should be restricted to holders of "diffuse collective" or "homogeneous individual" interests that are threatened or harmed" 34 . As such, the numerosity requirement was not established. The question will become increasingly relevant as the PA mechanism may, and should, encompass nowadays also the protection of effective competition.

On the other hand, the PAA, like traditional American class actions, tries to protect the interests of those who have not opted out, controlling the adequacy of representation. The need to ensure that the claimant acts as a representative, and does not favour its own interests sacrificing the interests of other members of the class, justifies some of the solutions established in the PAA. First, within the scope of judicial review, the Public Prosecutor, besides representing the State or other public authorities authorized by law, may substitute the applicant of a withdrawn suit. The Public Prosecutor may also act against transactions or injurious behaviours concerning the interests of those that did not opt-out (Article 16 PAA). Second, the judge plays a fundamental role in the application of the Portuguese mechanism as he/she may dismiss the petition on the ground that "it is manifestly unlikely to merit the application" (Article 13 PAA). The judge can collect evidence and is not bound by the initiative of the parties (Article 17 PAA), he/she decides on the court costs and expenses, as well as on the need to give the action a suspensive effect in order to prevent irreparable damages or difficult to repair (Article 18 PAA). The Portuguese solutions, apparently, fit well with those proposed by some authors that support "strong judicial checks as to admissibility of each action" in order to avoid abuses such as opportunistic behaviour of the lawyer' representing the class ${ }^{35}$.

The other controversial issue in the PAA is how to decide compensation for damages when only some of the injured parties are individually identified. According to Article 22(2) PAA, "[c]ompensation for infringement of interests of holders not individually identified is fixed in total" by the court. In addition, the right to damages shall be extinguished within three years from the final judgment that has recognized the damage; the rights corresponding to prescribed amounts shall be delivered to the Ministry of Justice, which will create a special account and allocate the payment of attorney fees and to support access to the courts (Article 22. ${ }^{\circ}$ n. ${ }^{\circ}{ }^{\circ}-4$ and n. 5 PAA).

33 J. Douglas Richards, "Aggregation of...”, op. cit., p. 129.

34 H.S. Antunes, "Class Actions...", op. cit., p. 163.

35 A. Andreangeli, "A view from...”, op. cit., p. 247. 
Doubts arise, however, about the possibility of allowing an entity another other than the court to distribute the total compensation among the injured parties that come forward in the prescribed 3 year period. The PAA does not clarify this issue. It has been suggested ${ }^{36}$ that one of the solutions would be to apply Article 31 of the Securities Code, which provides: "[T] he conviction obtained should indicate the entity in charge of the receipt and management of the indemnity due to those shareholders not individually identified, according to the circumstances (...)". In competition cases, consumer associations might be the most adequate entity to distribute the total amount of the compensation. However, as the law does not provide such solution, this will depend on the court's decision.

Finally, concerning the practical relevance of the PAA, consumer associations were able to initiate law suits in Portugal and the instrument of the PA has been successfully used for that purpose. The most relevant case here is $D E C O$ vs Portugal Telecom, where competition law was invoked, even if the case was decided on other grounds. In this case, the telecoms incumbent imposed an unlawful "activation charge" on all clients concerning all phone calls; DECO (a consumer association) sued Portugal Telecom on behalf of all these clients. In spite of the argument presented by DECO that the contested practice should be considered an abuse of a dominant position, Portuguese courts ${ }^{37}$ overlooked that argument and decided to consider the application successful on other grounds ${ }^{38}$. Following this judgement, DECO and Portugal Telecom arrived at a settlement at an estimated 120 million EUR. This amount was not, however, paid in direct payments but in free national calls for all Portugal Telecom's clients on several consecutive Sundays.

\section{Contingency fees - the Polish experience}

Another concern raised by the Commission in its Recommendation involves lawyers' remuneration. Section 29 of the Recommendation states that "[t]he Member States should ensure that the lawyers' remuneration and the method by which it is calculated do not create any incentive to litigation that is unnecessary from the point of view of the interest of any of the parties". However, litigation would always go against the interests of at least one party

36 S. Rossi, M. Sousa Ferro, "Private enforcement...”, op. cit., pp. 78-79.

37 The case took approximately 4 years, finally the Supreme Court decided in 2003: Supreme Court Decision - Portuguese Consumer Protection Association (DECO) v Portugal Telecom (7.10.2003).

38 Note, however, that, as Rossi and Ferro argued - cf. cit., p. 66, implicitly this judgement confirmed that the PA may be used in antitrust private enforcement cases. 
involved in the dispute (especially since those interests are diverse). Litigation should be a last resort because of the high legal costs involved and protracted proceedings. It seems that it would clarify more than it would confuse to say that lawyers' remuneration should not create an incentive to start litigation unnecessary for (sound) administration of justice.

Section 30 of the Recommendation specifies further that ,[t]he Member States should not permit contingency fees which risk creating such an incentive. The Member States that exceptionally allow for contingency fees should provide for appropriate national regulation of those fees in collective redress cases, taking into account in particular the right to full compensation of the members of the claimant party". In the Communication, contingency fees are depicted in three aspects: 1) as one of the features of the US legal system that "have made class actions a particularly powerful instrument that is, however, feared by those on the defending side, namely trade and industry as it can be used as a forceful tool to compel them to settle a case, which may not necessarily be well-founded" (para 2.2.2);2) as one of the details noted by the European Parliament in its 2012 Resolution ${ }^{39}$ and spoken of by some stakeholders who responded the Commission's 2011 public consultation on collective redress; they consider excluding contingency fees from the scope of the EU horizontal framework as an important safeguard against abusive litigation (paras 2.3 and 3.9.1); and 3) as a beneficial feature, that is, a useful method of financing collective actions - according to other stakeholders (para 3.9.1).

The concept of contingency fees has recently been established in Poland in the legal framework for collective redress. Group actions and their features, such as contingency fees, emerged in Poland a few years ago. The Polish Parliament adopted on 17 December 2009 the Act on the Pursuit of Claims in Group Proceedings (hereafter: APCGP) ${ }^{40}$. This legislative development was in line with the Commission's continuous efforts to facilitate access to justice, including effective redress. Just one year before, the Commission published its Green Paper on consumer collective redress ${ }^{41}$. The Polish legislature chose an opt-in model, as opposed to the opt-out system which exists in some European countries, including Portugal as shown above. The possibility to opt-in and to benefit from collective redress in accordance with the APCGP does not apply to group lawsuits seeking to protect personal rights ${ }^{42}$.

39 The European Parliament's resolution "Towards a Coherent European Approach to Collective Redress" of 2.02.2012, 2011/2089(INI), available at http://parltrack.euwiki.org/ dossier/2011/2089\%28INI\%29 (1.08.2014).

40 Journal of Laws 2010 No. 7, item 44. The Act came into force on 19.07.2010.

$41 \operatorname{COM}(2008) 794,27.11 .2008$.

${ }^{42}$ See in more detail A. Piszcz, “'Class Actions' in the Court Culture of Eastern Europe” [in:] L. Ervo, A. Nylund (eds), The Future of Civil Litigation - Access to Courts and Court 
Article 5 APCGP provides that " $[\mathrm{t}]$ he agreement regulating the remuneration of the legal representative may determine the remuneration proportionally to the amount awarded in favour of the claimant, but not beyond $20 \%$ of the said amount". American-style contingency fees do not seem to fit into the Polish legal environment. Polish ethics rules place limits on the use of contingency fees. Remuneration proportional to the amount awarded in favour of a claimant cannot be used as the only form of remuneration. However, it is permissible to agree on an additional payment to accompany basic remuneration, which would depend on the positive result of the proceedings. On the other hand, it is unclear - and even doubtful - whether contingency fees agreed upon pursuant to Article 5 APCGP can be charged to a losing defendant according to the "loser pays" principle. It seems that the court cannot charge more than the maximum amounts stipulated in the fees regulations ${ }^{43}$ with respect of individual actions ${ }^{44}$.

The explanatory notes to the draft APCGP clarify that the legal basis for contingency fees was introduced because of the need to make professional lawyers interested in engaging in complex group proceedings ${ }^{45}$. Class counsel is expected to do a remarkable job of representing group interests. The authors

Connected mediation in the Nordic Countries, Springer International Publishing Switzerland, Cham 2014, pp. 368-369.

43 Regulation of the Minister of Justice of 28.09.2002 regulating the issue of fees for advocates' activities and incurring by the State Treasury the costs of unpaid pro bono legal aid (rozporzadzenie Ministra Sprawiedliwości z dnia 3 października 2002 roku w sprawie optat za czynności adwokackie oraz ponoszenia przez Skarb Państwa kosztów nieoptaconej pomocy prawnej udzielonej z urzędu), consolidated text Journal of Laws 2013, item 461; Regulation of the Minister of Justice of 28.09.2002 regulating the issue of fees for legal counsels' activities and incurring by the State Treasury the costs of unpaid pro bono legal aid (rozporzadzenie Ministra Sprawiedliwości z dnia 28 września 2002 roku w sprawie opłat za czynności radców prawnych oraz ponoszenia przez Skarb Państwa kosztów nieopłaconej pomocy prawnej udzielonej z urzędu), consolidated text Journal of Laws 2013, item 490.

${ }^{44}$ See also M. Sieradzka, Ustawa o dochodzeniu roszczeń $w$ postępowaniu grupowym. Komentarz, Warszawa Wolters Kluwer 2010, pp. 143-144; T. Jaworski, P. Radzimierski, Ustawa o dochodzeniu roszczeń w postępowaniu grupowym. Komentarz, Warszawa CH Beck 2010, pp. 165-166; T. Ereciński, P. Grzegorczyk, "Effective protection of diverse interests in civil proceedings on the example of Polish Act on Group Action" [in:] Recent trends in economy and efficiency of civil procedure, Vilnius University Press, Vilnius 2013, p. 38. On the other hand, P. Pietkiewicz is of the opinion that contingency fees cannot be charged to a losing defendant even in part; P. Pietkiewicz [in:] M. Rejdak, P. Pietkiewicz, Ustawa o dochodzeniu roszczeń w postępowaniu grupowym. Komentarz, LexisNexis, Warszawa 2011, p. 130.

45 See http://orka.sejm.gov.pl/proc6.nsf/opisy/1829.htm (1.08.2014). Still, sometimes explanatory notes to draft bills do not state in full the legal, policy and other reasons for its preparation (sometimes there are also some "hidden" reasons). Another question is whether one can have the comfort of believing that legislature is rational. 
of the draft were afraid that few lawyers would be interested in taking on such cases unless they were financially incentivised by the APCGP itself.

Might that view be considered naive? Such an assessment would be too harsh. First, it should be emphasised that the introduction of the APCGP did not cause a flood of group litigations in Polish courts. Newest statistics released by the Ministry of Justice ${ }^{46}$ reveal that 21 group action suits were filed in 2010 (all civil suits), increased to 38 (37 civil suits and one commercial suit) in 2011, and grew once more in 2012 totalling 39 (35 civil suits and four commercial suits). Further on, the statistics unveil a surprising new tendency: 2013 has been a landmark year with only 22 group action suits (all civil suits). In addition, advancing group claims based specifically on competition law infringements seems extremely unpopular. Not only do injured persons fail to use their privileges under the APCGP, preferring to simply suffer their losses resulting from antitrust violations, they do not even turn to individual private antitrust actions, which have rarely been "tested" in Poland so far ${ }^{47}$. Polish consumers seem to recognise the advantages of being part of Grouponesque programmes, but they do not seem very eager to apply the "there is power in togetherness" logic to their claims ${ }^{48}$. The existence of a legal basis for contingency fees in group proceedings has not prevented the drop in the number of group action suits that has occurred after the first few court rulings on group cases were delivered, nor has it averted the apparent lack of collective antitrust actions.

The second problem concerns the way in which the Commission "utilises" the right to full compensation in the Recommendation. Section 30 requires those Member States that decide to exceptionally allow for contingency fees to set out "appropriate" national rules governing their use in collective redress cases (is Article 5 APCGP "appropriate"?). In particular, the right to full compensation of the members of the claimant party should be taken into account. Many Member States, including Poland, recognise the principle of full compensation in their substantive civil laws. Moreover, its regulation is going to be harmonised. Yet this is going to happen in the field of private antitrust enforcement (see Article 2 section 1 of the Damages Directive). The Recommendation is intended to have a much broader scope of application.

46 “Pozwy zbiorowe w latach 2010-2013”, http://isws.ms.gov.pl/pl/baza-statystyczna/opra cowania-wieloletnie/ (1.08.2014).

47 Compare A. Jurkowska-Gomułka, "Private Enforcement of Competition Law in Polish Courts: The Story of an (Almost) Lost Hope for Development" (2013) 6(8) YARS 110. See also A. Jurkowska, "Antitrust Private Enforcement - Case of Poland" (2008) 1(1) YARS 59 et seq. 48 A. Piszcz, "Has class-action culture already hit Poland?" [in:] M. Etel, I. Kraśnicka, A. Piszcz (eds), Court Culture - Conciliation Culture or Litigation Culture?, Białystok 2014, p. 138. 
The question then arises: does the Commission - placing the right to full compensation in Section 30 of the Recommendation (soft law instrument!) want to introduce this right (principle) into all Member States through a back door? Or, perhaps, should this right be taken into account only by those Member States which already have it in their national laws but not by others?

The Polish version of contingency fees (in group proceedings) should be defended, if only it could save the use of collective redress mechanisms in Poland. Does the Recommendation allow for any such "defence" by a Member State, other than simple disrespect for the Recommendation which is, after all, only a soft law instrument? A short review of the Recommendation leads to the conclusion that it seems to leave some "back doors" open for national solutions different from those being recommended by the Commission. One of them seems to lie in Section 2 of the Recommendation where it is suggested that the principles for collective redress mechanisms should "be common across the Union, while respecting the different legal traditions of the Member States". The Commission seems thus to be willing to integrate its current visions for collective redress with national legal traditions of EU Member States. The longer contingency fees will exist in Poland, the stronger they might contribute to the Polish legal tradition.

The second "back door" for exceptions to the principles set out by the Recommendation, by law or by court order, is envisaged in some instances where such exceptions are duly justified by reasons of sound administration of justice (see Sections 21, 22, 23 and recital 20 of the Preamble of the Recommendation). However, this rule refers only to the constitution of the claimant party and admissibility of collective actions, not to lawyers' remuneration. Nevertheless, it will be very interesting to see how the notion of sound administration of justice will be interpreted. The question here is, in particular, whether it will be taken to mean that what is "sound administration of justice" is different in various Member States (like legal traditions are different) or that there is, in fact, only one standard thereof for all Member States (the "average", a common denominator for e.g. Italian and Swedish administration of justice).

Finally, there is an open "back door" in Section 30 of the Recommendation. But what does it mean to take "into account [...] the right to full compensation"? In Poland, the fees regulations ${ }^{49}$ stipulate what maximum fees can be charged to a losing party by the court. Since those maximum amounts are relatively low in many categories of cases, it is often true that the actual fees paid to a lawyer are higher than the ones reimbursed later from the party obliged to do so by the court. Does it mean that Polish solutions regarding all court proceedings

49 See footnote 43. 
do not take into account the principle of full compensation? One should not underestimate here the value of another principle of civil law, namely the freedom of contract. It lets a party who ultimately wins a case to agree to pay its lawyers more than what the court can charge to the opposing party. So, why should it not be possible to do this in the form of contingency fees (in case of group proceedings)? Why should the latter be treated differently from the perspective of the right to full compensation? Surely, these questions are justified with regard to opt-in group proceedings. On the other hand, the opt-out model does not offer a comparable freedom of contract for group (class) members with respect to lawyers' remuneration. It should be argued, however, that contingency legal fees may contribute to abusive litigation but only in conjunction with the opt-out system ${ }^{50}$.

To sum it up, the Recommendation needs to be changed in some respects if it is to be accepted by all Member States. Adjusting their laws to the Recommendation would be a bit easier if at least the Damages Directive did not contradict the Commission's emphasis on collective redress. Recital 7 of the Preamble of the Recommendation lists competition and consumer protection alongside environmental protection, protection of personal data, financial services legislation and investor protection as areas where supplementary private enforcement of rights granted under EU law in the form of collective redress is of value. At the same time, however, Recital 12 of the Preamble to the Damages Directive declares: “(...) This Directive should not require Member States to introduce collective redress mechanisms for the enforcement of Articles 101 and 102 of the Treaty (...)”. It is worth adding that the quoted text was already present in the very first version of the draft Damages Directive circulated at the same time as the publication of the Commission's Recommendation on its website.

\section{Actions for damages based on breaches of EU competition rules}

\section{Prohibition of overcompensation}

Pursuant to the above-mentioned Article 2 of the Damages Directive: "1. Member States shall ensure that any natural or legal person who has suffered harm caused by an infringement of competition law is able to claim and to obtain full compensation for that harm.

\footnotetext{
50 See also summary of the Competition Law Association Panel Session "The dynamic between UK and EU Private Actions Reforms” of 9.09.2013, p. 4; http://www.competitionlawassociation. org.uk/new/events.htm (1.08.2014).
} 
2. Full compensation shall place a person who has suffered harm in the position in which that person would have been had the infringement not been committed. It shall therefore cover the right to compensation for actual loss and for loss of profit, plus payment of interest.

3. Full compensation under this Directive shall not lead to overcompensation, whether by means of punitive, multiple or other types of damages".

The principle of full compensation is one of the major principles of civil law in continental Europe. Notably, exceptions to this principle exist for instance in the field of intellectual property protection. The most impressive examples of legal solutions capable of overcompensating persons injured by competition law infringement can be found outside continental Europe. In England and Wales, non-compensatory damages can be awarded in addition to compensatory damages ${ }^{51}$. One of the latest developments in English private antitrust enforcement was the judgment of the Competition Appeal Tribunal (hereafter: CAT) related to a damages claim submitted by 2 Travel Group PLC (in liquidation) against Cardiff City Transport Services Limited ${ }^{52}$. It was the first CAT ruling to award antitrust damages concerning the infringement of the prohibition of the abuse of a dominant position (in national law). At the same time, it was the first ruling (in England) to award exemplary damages to an applicant injured by an antitrust infringement. The applicant was awarded GBP 33.818,79 in compensatory damages plus exemplary damages of GBP $60.000,00$. One of the reasons behind such a decision was that the relevant national competition authority (hereafter: NCA) did not fine the defendant for the above infringement; the violation was qualified as conduct of minor significance. Of particular importance is the English standpoint that the principle of non bis in idem precludes the award of exemplary damages in cases where the defendants have already been fined (or had fines imposed and then reduced or commuted $)^{53}$.

All of the debate seems to centre on the function(s) of antitrust damages. According to the CAT, the imposition of fines and an award of exemplary damages serve the same aim: namely to punish and deter anti-competitive behaviour ${ }^{54}$. Not only should injured persons be compensated by infringers of competition rules, the latter should also be punished because they deserve it. Under English laws, courts that decide on antitrust damages are competent to

\footnotetext{
51 See C.A. Jones, Private Enforcement of Antitrust Law in the EU, UK and USA, OUP, New York 1999, p. 201.

52 Judgment of 5.07.2012 in Case 1178/5/7/11. For more information visit http://www. catribunal.org.uk/238-7662/Judgment.html (1.08.2014).

53 See the CAT judgment of 5.07.2012, para. 491; R. Whish, Competition Law, Oxford NY OUP 2009, p. 303.

${ }^{54}$ See the CAT judgment of 5.07.2012, para. 491.
} 
question the decision of the NCA that there was no need to punish and deter anti-competitive behaviour; courts are capable of making corrections thereto in the form of an award of exemplary damages. The EU moved towards the continental standard, namely the prohibition of overcompensation, whether by means of punitive, multiple or other types of damages, and England will be obliged to fully comply with the EU approach (unless it disregards the Recommendation).

The Damages Directive shall set a very definite boundary between public and private antitrust enforcement. EU institutions do not want national courts to make the above-mentioned corrections to public enforcement decisions (with respect to Articles 101 and 102 TFEU) - they do not want public antitrust enforcement functions to be complemented in the above manner. But is an absolute guarantee of the inviolability of the boundary between public and private antitrust enforcement necessary? Certainly, national courts should not be permitted to perform such a "corrective" function in a case of leniency-based immunity from fines. Private enforcement should not interfere with leniency programmes; it should not undermine the effectiveness of public antitrust enforcement. But if an NCA is able to desist from the imposition of fines because of the low turnover of an infringer (in such circumstances a fine could neither punish nor deter anti-competitive behaviour), why not allow for an award of exemplary damages later when the court is deciding on an application for damages and the infringer's financial standing is not as weak as it was earlier?

As a rule, Polish laws do not seem to allow for overcompensation in private antitrust enforcement. However, also Polish legal provisions might generate legal interpretation problems in the light of Article 2 of the Damages Directive. First, there is still no unambiguous answer to the question identified under Article 2 APCGP, that is, whether standardisation of group claims can be seen as an exception to the principle of full compensation. If so, does it only allow for under-compensation or also for overcompensation ${ }^{55}$. Another problem that may appear in Poland after the implementation of the Damages Directive is how to treat cases where the infringement of EU competition rules in the Polish territory constitutes at the same time an act of unfair competition. In case of such conjunction, an injured person has the right to pursue claims determined by Article 18 of the Act of 1993 on Combating Unfair

55 The insights into this problem are provided in e.g. T. Jaworski, P. Radzimierski, Ustawa o..., op. cit., p. 109 et seq.; M. Rejdak, P. Pietkiewicz, Ustawa o..., op. cit., p. 74 et seq.; A. Jurkowska-Gomułka, Publiczne i prywatne egzekwowanie zakazów praktyk ograniczajacych konkurencję, Warszawa Wydawnictwo Naukowe Wydziału Zarządzania Uniwersytetu Warszawskiego 2013, p. 204. 
Competition ${ }^{56}$ including an award of an adequate amount for a determined social goal connected with the support of Polish culture or related to the protection of national heritage (where the act of unfair competition has been intentional). It seems that the focus here should be on an injured person, and not on the infringer. Just because the latter is obliged to pay more than "exact" compensation, this does not necessarily mean that the injured person is overcompensated; there is no strong link of this type because whom the money is paid to should also be taken into account. However, even if the injury was sustained by a social organisation, which applied for, and indeed received, an award of an adequate amount of money for its own social goal (apart from compensation), it would still be fair to say that the organisation was not being overcompensated. Such an award, despite being given directly to an injured party, would have, however, a different "destination" in terms of its function (different than compensation of an injured party as it is with English exemplary damages).

\section{Joint and several liability}

One of the biggest changes required by the Damages Directive, at least with respect to Polish laws, is going to relate to joint and several liability. Article 11 section 1 states that "Member States shall ensure that undertakings which have infringed competition law through joint behaviour are jointly and severally liable for the harm caused by the infringement of competition law (...)". Polish laws contain no particular legal basis for joint and several liability of co-infringers of competition law. A general legal basis can now be found in Article $441 \S 1$ of the Civil Code $^{57}$ which stipulates that if several persons are liable for harm caused by tort, their liability shall be joint and several ${ }^{58}$. The concept of "unity of harm" is a prerequisite for joint and several liability ${ }^{59}$. This feature exists if the harm is indivisible by its nature, that is, committing the same tort by co-infringers is interrelated with the indivisibility of consequences resulted from it. Such "unity of harm" exists where it results from the joint operation of harmful factors so that it is impossible to distinguish which factor caused/ contributed to what part of the harm. It is up to the circumstances of the case to determine that in order for the harm to appear, harmful factors had to coexist. The implementation of Article 11 section 1 of the Damages

56 Consolidated text Journal of Laws of 2003 No. 153, item 1503, as amended.

57 Consolidated text Journal of Laws 2014, item 121, as amended.

58 See also P. Podrecki, "Civil Law Actions in the Context of Competition Restricting Practices under Polish Law" (2009) 2(2) YARS 87.

59 Supreme Court judgment of 20.11.2002 in Case II CKN 859/00. 
Directive into Polish laws will certainly clarify whether liability for competition law infringements is joint and several. Such a provision will also not be regarded as a "strange" legal transplant.

To say the same of the implementation into Polish laws of Article 11 section 2 of the Damages Directive may be somewhat less grounded. This provision was inserted into the draft almost at the last minute. Referring to the limitations of joint and several liability of small and medium-sized enterprises (SMEs), it constitutes a kind of de minimis rule. Member States shall ensure that where the infringer is a SME, it shall be liable only to its own direct and indirect purchasers under some specified conditions. Polish law does not know any similar limitations of civil liability. The above concept (the de minimis rule) seems an example of unprecedented mixture of civil (private) legal provisions and regulatory rules. It is not the first time for an EU directive to require national legislatures to intervene in private laws for some EU policy reasons. There is a strong case for such requirement when it comes to leniency applicants (which will be discussed below). It is understandable that a limitation of civil liability of leniency applicants ${ }^{60}$ (despite being at the same time a limitation for private antitrust enforcement) may create an incentive for companies to cooperate with competition authorities. As such, it might considerably improve the efficiency of public antitrust enforcement. But is there any solid rationale behind the limitations of civil liability of SMEs? The economic importance of micro-enterprises and SMEs is unquestionable; on the other hand, one of their main problems is often their lack of knowledge about competition rules. However, tinkering with their civil liability does not seem an appropriate form of public support for SMEs. For economic reasons, however important they might be, EU institutions are improving the situation of some SMEs. Yet at the same time, they may make it far more difficult for injured persons to get compensation ${ }^{61}$, including injured entities such as other SMEs and even weaker market participants such as consumers etc. The above de minimis rule on joint and several liability is simply favouring some SMEs.

60 According to Howard, it is a sensible reinforcement to the attractiveness of the leniency regime; A. Howard, "Too little, too late? The European Commission's Legislative Proposals on Anti-Trust Damages Actions" (2013) 4(6) Journal of European Competition Law \& Practice 458.

61 A similar concern was expressed by Kersting with respect to the limitation of civil liability of leniency applicants ("While it does generally make sense to privilege successful leniency applicants with regard to their civil liability, it is problematic to do so at the expense of the injured parties. (...) According to Article 11(2) some victims can only claim compensation from successful immunity applicants if they prove that they cannot obtain full compensation from the other cartelists. This puts a significant burden on them which renders their right to full compensation less effective."); see Ch. Kersting, "Removing the Tension Between Public and Private Enforcement: Disclosure and Privileges for Successful Leniency Applicants" (2014) 5(1) Journal of European Competition Law \& Practice 4. 
It is worth mentioning, however, that it will not be easy for SMEs to meet the conditions stipulated in Article 11 section 2 (and, first of all, to even interpret them $^{62}$ ). One of the conditions is that "the application of the normal rules of joint and several liability would irretrievably jeopardize its [enterprise's] economic viability and cause its assets to lose all their value". A difficulty will probably be hidden in the adjective "all". It will not be easy for a SME to prove that all its assets would lose their entire value if normal liability rules were applied.

Another challenge for the Polish legislature will be to implement Article 11 section 3 of the Damages Directive, which relates to limitations of joint and several liability of leniency applicants and, more precisely, immunity recipients. Pursuant to Article 4(19) of the Damages Directive, the term "immunity recipient' means an undertaking or a natural person which has been granted immunity from fines by a competition authority under a leniency programme". It does not cover undertakings and persons who have been granted a partial fine reduction. Leniency programmes are defined in Article 4(15) of the Damages Directive as "a programme concerning the application of Article 101 TFEU or a corresponding provision under national law on the basis of which a participant in a secret cartel, independently of the other undertakings involved in the cartel, cooperates with an investigation of the competition authority (...)". Finally, the term cartel shall be understood here as an agreement or concerted practice between two or more competitors ${ }^{63}$. Recital 34 of the Preamble to the Damages Directive clarifies that it is appropriate to protect immunity recipients from undue exposure to damages claims because they ,play a key role in detecting secret cartel infringements and in bringing these infringements to an end, thereby often mitigating the harm which could have been caused had the infringement continued". However, as Schwab rightly observed, it is hard to diagnose "undue exposure to damages claims" seeing as so far no evidence has come to light to suggest that the proposed Directive will lead to immunity recipients being the first, or only target to be sued $^{64}$.

Pursuant to Article 11 section 3 of the Damages Directive “(...) Member States shall ensure that an immunity recipient is jointly and severally liable: (a) to its direct or indirect purchasers or providers; and (b) to other injured parties only where full compensation cannot be obtained from the other

${ }^{62}$ Member States will need almost technical guidance on a wide range of issues relating to those conditions.

63 Art. 4(14) of the Damages Directive.

64 A. Schwab, "Finding the Right Balance - the Deliberations of the European Parliament on the Draft Legislation Regarding Damage Claims" (2014) 5(2) Journal of European Competition Law \& Practice 66. 
undertakings that were involved in the same infringement of competition law (...)". As Howard rightly asked with regard to the first wording of the liability privilege (where words "are unable" were used instead of "cannot"), in what circumstances will it be "impossible" for claimants to obtain compensation from other infringers ${ }^{65}$ ? It is unclear whether "cannot" refers to a legal ban (prohibition) or a practical impediment (such as one of the infringers going into liquidation) or both.

There are apparent tendencies of the EU and its Member States to converge in many areas of competition law and many national antitrust concepts closely resemble their EU prototypes. Nevertheless, the Polish leniency programme, set out in the 2007 Competition and Consumers Protection Act ${ }^{66}$, differs from its EU equivalent to a considerable extent. First and foremost, an important dimension of Polish leniency is that it refers not only to cartels but also to other agreements (and practices), including vertical agreements. This particular discrepancy will remain even after the recent amendment of the Polish programme, which is going to come into effect as of 18.01.2015 (the amendment introduces another variant of leniency, namely the leniency plus programme). So, what should be the scope of the rule implementing Article 11 section 3 of the Damages Directive? Shall the Polish legislature extend it beyond those cartel participants that have received immunity from fines?

The discussed provision is specifically "tailored" to cartel participants. It is not impossible, however, for a participant in a secret vertical agreement covered by Article 101 TFEU (as well as the Polish Competition Act of 2007) to report an infringement to the Polish NCA under its leniency programme. Such entity shall be granted immunity from antitrust fines but not from normal (regular) joint and several liability. In fact, this is an excellent opportunity to ask: do NCAs need such leniency applications? Do "non-cartel" infringers deserve incentives and privileges similar to those granted to cartel participants? After all, it can be argued that cartel practices (to which the liability privilege is attached) are much more dangerous to market competition than other anticompetitive agreements. Still, the possibility of extending the liability privilege to cover non-cartel leniency applicants seems doubtful. Article 11 section 3 of the Damages Directive seems to be conceived as a full harmonisation clause (rather than a minimum harmonisation clause). It does not involve expressions such as "at least" 67 , "wider" 68 or any other word that would suggest that Member States can extend the scope of the

65 A. Howard, "Too little...", op. cit., p. 458.

66 Competition and Consumers Protection Act of 16 February 2007 (Journal of Laws 2007 No. 50, item 331, as amended).

67 See Art. 9 section 2, Art. 10 section 3.

68 See Art. 5 section 8. 
liability privilege (and establish a higher standard of protection of entities cooperating with competition authorities). Of course, Member States are free to do this with respect to competition law infringements of a purely national scope. However, it seems much more rational for Member States to have identical, or almost identical, solutions with respect to infringements of EU and national antitrust rules. Putting it colloquially, if we dig dipper and look wider, we shall notice that perhaps it is too early for the harmonisation of the liability privilege seeing as Member States are allowed to maintain differences with respect to national leniency programmes.

\section{Effect of national antitrust decisions}

Last but not least, the effect of national antirust decisions on private antitrust enforcement is an example of a solution where the Council and the Parliament have somewhat decided that one "size" cannot fit all, despite the fact that the Commission was initially of a different opinion. EU institutions gave a proper consideration to a range of options in this context. First, the Commission's version of the draft Damages Directive of June 2013 repeated the scheme of Article 16 of Regulation 1/200369. Accordingly, Article 9 sentence 1 of the draft Damages Directive stated originally that: "Member States shall ensure that, where national courts rule, in actions for damages under Article 101 or 102 of the Treaty or under national competition law, on agreements, decisions or practices which are already the subject of a final infringement decision by a national competition authority or by a review court, those courts cannot take decisions running counter to such finding of an infringement". The draft provided therefore for a (German-like) cross-border binding effect of national antitrust decisions. However, national judiciaries tend to enjoy much discretion with regard to findings contained in infringement decisions adopted in other Member States. Many of them leave no room for any schemes other than the non-cross-border binding effect of national decisions (e.g. England and Wales) ${ }^{70}$. Importantly, it was not until 2005 that Germany introduced cross-border binding effect of national antitrust decisions into its Act against Restraints of Competition, amongst some other important innovations affecting the national system of private antitrust enforcement.

The German "product" was not desired to be taken as an EU-wide model. After works in the Council, Article 9 of the draft Damages Directive was transformed in November 2013; the authors of the revised draft introduced

69 Council Regulation 1/2003 of 16 December 2002 on the implementation of the rules on competition laid down in Articles 81 and 82 of the Treaty (OJ L 1, 4.01.2003).

70 See also A. Howard, “Too little...", op. cit., p. 457. 
a double standard in two separate sections concerning - respectively - the non-cross-border and the cross-border effect of national decisions. Emphasis was placed on the probative effect of national decisions instead of their binding effect. Section 1 sentence 1 argued that "Member States shall ensure that an infringement of competition law found by a final decision of a national competition authority or a review court is deemed to be irrefutably established for the purposes of an action for damages brought before their national courts under Article 101 or 102 of the Treaty or under national competition law". Instead of the requirement that court rulings cannot run counter to a finding of an infringement, the new Article 9 section 1 provided for an irrefutable (irrebuttable, absolute) presumption of an infringement. With respect to the cross-border effect of national decisions, Article 9 section 2 stated that "Member States shall ensure that a final decision (...) given in another Member State can be presented before their national courts as evidence, among other, of the fact that an infringement of competition law has occurred".

The newest version of Article 9 of the Damages Directive, ultimately adopted by the Parliament in April 2014, differs from the one of November 2013 in that in section 2 it says that "Member States shall ensure that a final decision (...) given in another Member State may, in accordance with their respective national law, be presented before their national courts as at least prima facie evidence that an infringement of competition law has occurred and, as appropriate, may be assessed along with any other material brought by the parties". Article 9 section 2 constitutes a minimum harmonisation clause that accounts for an "at least half-probative" cross-border effect of national antitrust decisions.

It seems that the reason for such clause lies in the fear of the differences existing in some procedural standards between Member States. It might therefore happen that a Member State would be bound by a "foreign" (other Member State) decision adopted in circumstances in which such decision would not have been adopted in this Member State. In the draft report on the proposal for the Damages Directive, the Committee on Economic and Monetary Affairs in the European Parliament argued that "the binding effect shall not apply in cases where obvious errors occurred during the investigation of facts or where the rights of the defendant were not duly respected during the procedure before the national competition authority or competition court"71. However, taking this into account, EU institutions decided not to declare that decisions of other EU NCAs' may be non-binding in all Member States. They gave Member States a choice whether they want their courts

71 Draft Report of 3.10.2013, available http://www.europarl.europa.eu/sides/getDoc. do? pubRef $=-/ / \mathrm{EP} / / \mathrm{NONSGML}+\mathrm{COMPARL}+\mathrm{PE}-516.968+01+\mathrm{DOC}+\mathrm{PDF}+\mathrm{V} 0 / / \mathrm{EN} \&$ langu age $=$ EN, p. 37 (1.08.2014). 
to be: 1) bound by those decisions; 2) governed in their assessments by an irrefutable or rebuttable presumption; 3 ) obliged to treat them as a piece of evidence and to freely assess their weight and probative value; 4) obliged to treat them as prima facie evidence. Member States that have one of these solutions in place already shall be considered as complying with Article 9 section 2 of the Damages Directive.

Polish civil procedure law recognises only the binding effect of criminal court rulings, but not of decisions issued by administrative bodies (such as NCAs). Whereas, for instance, in civil cases, courts are bound by findings of a criminal court ruling regarding bid-rigging, at the same time they may be presented with an administrative decision as only evidence which may be assessed along with any other material brought by the parties ${ }^{72}$. Polish law has no provisions on the binding effect of decisions of NCAs, not even with respect to the Polish NCA, let alone those of other Member States. It is worth adding that jurisprudence thereon has so far not been uniform ${ }^{73}$.

Hypothetically speaking, Poland seems to be in a tabula rasa situation and free to select one of above-mentioned competing solutions. Should the legislator choose the minimal solution in the form of prima facie evidence? If so, this approach would face a fundamental difficulty. So far, prima facie evidence has not been codified in Polish civil procedure at all. In fact, it has been used by courts in cases concerning injuries that occurred during medical treatment ${ }^{74}$. The first central difficulty here is that neither judges nor scholars are unanimous on what prima facie evidence is in Polish legal culture. Some argue that it is similar to the de facto presumption (Article 231 of the Civil Procedure Code ${ }^{75}$ ). Others believe that prima facie evidence makes the existence of certain facts only plausible ${ }^{76}$.

72 See resolutions of the Supreme Court of resolutions of 16.06.1994, Case II PZP 4/94, and of 9.10.2007, Case III CZP 46/07.

73 A. Jurkowska-Gomułka, "W stronę umocnienia prywatnoprawnego wdrażania zakazów praktyk ograniczających konkurencję - glosa do uchwały SN z 23.07.2008 r. (III CZP 52/08)" (2010) 5 Europejski Przeglad Sadowy 43-48; A. Piszcz, "Still-unpopular Sanctions: Developments in Private Antitrust Enforcement in Poland After the 2008 White Paper" (2012) 5(7) YARS 62-66; A. Piszcz, "What type of sanctions? Prospects of private enforcement of EU competition law in Poland" [in:] Proceedings of the 55th International Scientific Conference of Daugavpils University, Daugavpils Universitāte Akadēmiskais Apgāds "Saule”, Daugavpils 2014, pp. 602-603; M. Sieradzka, "Dochodzenie roszczeń za naruszenie unijnych i krajowych reguł konkurencji a kwestie prejudycjalności rozstrzygnięć organów ochrony konkurencji” (2010) 12 Przegląd Prawa Handlowego 51-53.

74 See M. Białkowski, "Dowód prima facie w postępowaniu cywilnym dotyczącym szkód powstałych w związku z leczeniem” (2014) 3-4 Palestra 115-125.

75 Consolidated text Journal of Laws of 2014, item 101, as amended; (hereafter: CPC).

76 See Art. 243 CPC. 
Which national approach should be taken as a model for the interpretation of the notion of prima facie evidence in light of the Damages Directive (how is this notion construed in other Member States)? Its interpretation as making the existence of a given fact plausible would have large practical consequences. The creation of a legal rule whereby decisions issued by other EU NCAs make an infringement of competition law plausible will not improve the claimants' position. To do so, such rule would have to be accompanied by a provision stating that making an infringement plausible is sufficient, without the need of evidence. Otherwise, decisions of other EU NCAs' would only be a "beginning of the proof" and eventually, an infringement of competition law would have to be proven. From this point of view, one could imagine that the version of Article 9 section 2 that was devised in November 2013, which left no room for such doubts, would be much easier to comply with by all Member States.

It could certainly be argued that the Polish legislator does not have to choose the minimal solution, especially considering it seems so troublesome from the perspective of the national legal system. The highest standard solution (German-like) might be chosen instead or one of the options in-between. Of course, this is the quintessential advantage of the "minimum" harmonisation approach. However, this analysis leads to one far-reaching question. Is Article 9 section 2 of the Damages Directive going to contribute to the phenomenon of forum shopping 77 ? Is it capable of producing such a side effect? If claimants had at their disposal a final infringement decision adopted by any EU NCA, then, from the perspective of the effects of such decision, they would favour jurisdictions where courts are bound by such decisions. Going to a national judiciary that may freely assess the weight and probative value of such decisions would risk that an infringement might ultimately not be proven. It is likely that such situation will follow the transposition of the Damages Directive into national laws. However, harmonisation efforts were not meant to promote or encourage forum shopping and yet EU institutions must be prepared for it if considerable legal differences among the Member States remain. It is fair to be concerned how the different rules of the 28 Member States will provide for legal certainty for parties in cross-border litigations.

77 This phenomenon is analysed in many aspects in: J. Basedow, S. Francq, L. Idot, International Antitrust Litigation: Conflict of Laws and Coordination, Hart Publishing, Oxfrod-Portland 2012, pp. 6-7, 46-47, 52-53, 409-410 etc. 


\section{Conclusions}

In recent years, private antitrust enforcement has been one of the primary concerns of public discussions in the EU forum. The Recommendation and the Damages Directive will not automatically improve efficiency of private antitrust enforcement in Europe - they need to be implemented first. Their transposition will require Member States to conduct an intensive scrutiny of legal areas such as civil law, procedural law and competition law. Private antitrust enforcement is thus going to become a more highly regulated and codified field in EU Member States.

It was argued, on the basis of Polish experiences, that contingency fees with reasonable legal boundaries may be helpful in case of opt-in group proceedings, especially if the use of this instrument is diminishing. The Portuguese experience clearly suggests that the PA mechanism is potentially important. The existing model strengthens access to justice and effective redress, even if the current framework retains many limitations: scarce resources of consumer associations (contingency fee arrangements or pactum de quota litis fees are prohibited in Portugal), length of the proceedings, and uncertainties surrounding certain aspects of the PA, which may be clarified by juridical interpretation in the likely event that the PAA will not be revised in the near future ${ }^{78}$.

Furthermore, the Recommendation is not binding on EU Member States - it states that Member States can follow a different solution as long as it is justified. Only time will thus tell to what an extent will collective redress mechanisms be adopted throughout the EU. It remains to be seen also if there is a risk that Member States' solutions will differ to a large extent in terms of their effectiveness.

The Damages Directive, as a legally binding act, is of different nature. Member States will have to transpose it into their national legal systems. However, the above analysis of selected issues (prohibition of overcompensation, joint and several liability, effect of national decisions) shows that 28 national solutions create a puzzle that can pose difficulties when being harmonised according to the EU model. This is so especially because the latter is imperfect to some extent also. Some reservations can be expressed as to the use of minimum harmonisation clauses and the full harmonisation approach. It can be expected that literature will provide extensive critical commentary to some solutions provided in the Damages Directive.

78 There are particularly doubts concerning the decision and distribution of total compensation, which can be solved by the courts, applying the legal techniques of interpretations. This solution seems the most likely in the near future, although some voices suggest that "it would be useful if the PAA were revised", see Rossi - Ferro, op. cit., pp. 77-78. 